\title{
关于划分构造区的一些觀点和 思想方法問題
}

\author{
陈 国这 \\ （中南矿治学院地盾系大地构造研究室、中国科学院湖南地盾研究所）
}

目前，在我国构造区划分的問題上，还存在着 不一致的看法。有时，对于同一地区的基本上相同 的材料，两人分析所得的結論很不相同。在本文中， 笔者根据学习毛泽东思想的一些体会，試图对如何 正确运用历史分析法去划分构造区的有关覌点及思 想方法問題，提出几点初步意見。

笔者䚿为，在划分构造区的时候，必須从发展 观点，特別是不断发展观点去看一个地区的大地构 造性质及其变化。我們必須考虑到各个地区的全部 地盾发展史，收集抹分析每个地区每个地稹时期， 从最老直到最新时期的地质資料，特別是不可忽略 較新地盾时代的資料。因为事物是在不断运动、变 化和发展着的。一个地区大地构造性稹，在地壳的 发展过程中，也是不断演变、不断向前发展的。地壳 里面包含着活动与稳定两种对立的因素。由于这两 个对立面之間的矛盾斗爭，推动了地壳不断向前发 展。在地壳的不断发展过程中，凡活动因素占优势 及起主导作用的成为主要矛盾方面的某些地区的某 些发展阶段，垖表現为活动区。反之,則表現为“稳 定”区。因此，活动区与“稳定”区这两个矛盾着的 东西, 是可以在一定条件下互相轉变的。一个地区 在某一发展阶段可以是属于活动区的地槽区，而到 了另一发展阶段也可以轉化为属于“稳定”区的地台 区; 如果讋地区所經历的发展史較为复杂，則在地 台阶段之后的另一发展阶段，还会轉化为新的活动 区一一地洼区。“地槽一地台說”訩为地台是单純扩 张及稳固不变的，是地壳发展的最終形式; 有些人 扭且强調地台是十分稳定的、死的东西，他还用 “公式”表示地壳发展仅仅是由地槽区演变为地台
区。这种覌点和棓証唯物論关于事物不断运动、变 化和发展的基本原理是不相容的。它使某些人无洁: 理解地台阶段之后地壳継緷向前发展的事实。其次, 不同发展阶段之間是既互相区別而又互相联系着 的，不能片段分割。我們必須把一个地区的地稹发 展史中各个不同发展阶段的事实看作不断发展过程 中的不可分割的部分，互相联系起来，而不可仅以 其中某一发展阶段的某一片段事实,加以过分强調， 即䚿作是䘫处地盾发展史的全部情况，而忽略了其 他发展阶段，特別是最新发展阶段的历史。例如， 我們不能仅仅因为看到一个地区某一时期的地槽型 特征, 臫訩为它的全部地稹发展过程仅仅是个地槽 区，而不去注意地槽阶段以后的新的变化。同样， 我們也不可以抓住一个地区某一时期的地台型特 征, 就訩为它的地稹发展史到达地台阶段垖停止不 前，而不去考虑継在地台之后的、更新的阶段的情 况。中国东南部奥湘桂一带，元古代至下古生代 时，曾經是个地槽区。这个地槽区于志留紀末結

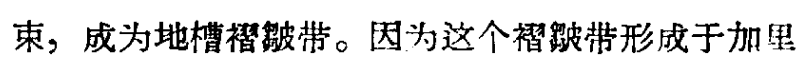
东期，故可称为加里东褶貱带。上古址代时，这个 古加里东褶貱带已逐濑被侵蝕夷平, 轉化为地台。 在这期間，作随着侵蝕作用的进行，在以下降运动 占优势的部分地区造成了地台的沉积盖层, 而古加 里东裙解带的残留部分師成为它的褶岈基底, 被沉 积盖层所盖复。因为这个地台区其前身的地槽是結 束于加里东期, 故可称为后加里东地台。可是, 到 中生代中期, 这个原为后加里东地台的地区, 又进 一步向前发展，轉化为地洼区了。所以，当我們說 任何一地区是什么大地构造性盾的时候, 必須有时 
間概念。除非指的是目前发展阶段的情况，否則都 应該說明所指的是那一个地盾时代。近年，对于中 国东南部的大地构造性稹問題，頗多孚論，有人說 它是地槽槢雅带，有人說它是地台区。由于这一地 区属于地槽型沉积的龙山踤时代問題，最近定为下 古生代，有人逐据此断定該处为一地槽区。其实地 槽区及地台区这两种锐法都有一定的根据，但都不 全面。地槽櫕雅带指的是下古生代的情况; 呚处在 泥盆䄫前确实筧經过加里东槢㿲带。地台区指的是 上古生代至中生代初期的情况; 当时确为一个后加 里东地台。而两种說法都沟有考虑到中生代中期以 来的新的变化。只要我們彼此有了不断发展覌点以 及与之联系的时閒覌念，就会看出过去这种无原則 的爭論是没有意义的。

其次，我們既要有不断发展覌点，同时还婹有 发展阶段覌点，持把二者統一起来。我們必須注意 所論地区各种地稹事实的发生时代和出現先后，把 不同时期的特点依其出現順序，依次排列，把它們 看作既互相联系而又互相区別，是事物在不断发展 中不同发展阶段的产物，抹据此来划分出主要发展 阶段。从而全面地了解該地区的形成过程和在各个 发展阶段中的重大变化，树諳識每个发展阶段的大 地构浩性稹, 正确地重塑其全部地稹发展史。因为 不同发展阶段有着不同的稹，不可把不同稹的阶段 的特点混在一起, 致使問題混清不清。例恻, 我們 不能把一个地区在其地稹发展史中以前的地台阶段 的地台型海相沉积, 和后来的地洼阶段的地洼型岩 浆活动混在一起, 作为說它是地槽区的証据。同样, 我們也不能把从前的地槽阶段的地壳运动，和經过 了后来地台阶段之后才出現的地洼型构造运动、沉 积作用和岩浆活动混在一起，把地注阶段的地壳运 动䚿作是以前的地槽型地壳运动的継續，說該处目 前仍为“地槽发展后期”的所謂“准地台”。中国东 部, 以华北而論,震且紀前已結束了地槽阶段; 震且 紀及古生代的、相对稳定的地台阶段，十分典型而 做长; 中生代中期以来的活动性再度高涨阶段和前 震旦紀的地槽阶段有着本稹上的差別，不能混为一 談。同样，华南东部奥桂湘韸一带的地槽阶段在泥 盆紀前已結束，而上古生代至中生代初所出現的、 相对稳定的典型的地台情况，以及中生代中期至新
生代的地洼型强烈活动的特征，都不能证明所謂目 前发展阶段是“地槽发展后期”的說法是符合实际 的。单从形式观点出发而不考虑各个不同发展阶段 之間的稹的差別，有如黃汲清的“多旋迴”颜所朵取 的, 其不正确之处, 垖主要在此。他們把这些地区 几个不同发展阶段的、不同性稹的地壳运动混为一 談, 把該处的地壳发展对程看作仅仅是数量上的变 化, 仅仅是重复几个“造山旋迴”而已! 由于这种形 而上学覌点的限制, 使他們无法訩識和說明中国东 部目前发展阶段的大地构造性稹。

把一个构造区和另一个构造区对比时，应畡以 它們的地稹发展史中的相当的阶段为准。例如, 我 們把中国东部这个构造区和俄罗斯地台对比的时 侯，应以中国东部中生代中期以前的地台阶段去和 俄罗斯地台的地台阶段相比較，而不应把中国东部 中生代以来的地注阶段去和俄罗斯地台的地台阶段 相比較。再者, 如果把中国东部的地洼阶段与以前 的地台阶段这两个性稹不同的阶段混作同一发展阶 段, 去和俄罗斯地台的地台阶段相比較, 也是同样 地没有意义的。有人把中国东部目前发展阶段的大 地构造性稹說成是 “活动性比标准地台为大”的所 謂“准地台”，抹訩为是中国特有的东西，就是由于 尔用了这种不正确的对比方法的緗故。

由于一个地区的大地构造性稹是不断发展、因 时而变的，划分构造区时应以目前发展阶段的大地 构造性稹为准絙。因为目前发展阶段是在以前各个 阶段的基础之上发展起来的。它通过以前所形成的 各个基本构造层, 把以前各个发展阶段的基本內容 經过揚奔而总継承下来。例如，地台区是由地槽区 轉化而成的, 它的代表地台阶段的沉积盖层是在代 表以前地槽阶段的褶皽基底上发展起来的，抹以此 把地槽阶段这个前身的基本內谷殌过揚奔后継承下 来。同样，地洼区是由地台区轉化而成的，它的地 洼沉积层是在代表以前地台阶段的沉积盖层上（有 时直接在代表地槽阶段的榴坡基底上) 成长起来的, 扭以此直接或間接把地台阶段和地槽阶段这两代前 身的基本內容經过揚弃后継承下来。所以，只有根 据目前发展阶段的大地构造性稹来确定这一地区在 大地构造图中的分区名称，才能总結出全面地反映 出該地区的全部地稹发展史和成矿作用发展史，才 
能总結出抹全面地反映出各个发展阶段的大地构浩 性质及其所成矿产在时間上和室間上的分布规 侓一一这些历代的矿产正是由目前的发展阶段通过 历代所形成的基本构造层总継承下来的。例如，中 国东南部前泥盆紀龙山萦所形成的加里东地槽裮酦 带, 在上古生代时已經逐濑被侵蝕夷平, 轉化为地 台; 至中生代中期，这个后加里东地台 又再度轉 化，成为地注区。我佩不能把該处前泥盆紀的古地 情区性稹作为在大地构造图中确定这一构造区名称 的根据，更不能把中生代中期以来所形成的、如同 今日所見的地洼袹断带的地貌看作是前泥徐紀的古 地槽袹解带的地貌。同样，中国东部在古生代时， 曾存在过一个辽䦣的“中国古地台”，但自中生代 中期以来，它的大部分已經轉化为地洼区。因此， 虽然在海西期末的一幅“中国古大地构造图”上，这 地区仍可称为“中国地台”，但进入强烈的太平洋运 动期，特別是其中的燕山运动分期以后，其大部分 应改称地洼区了，如华北地洼区、华南地洼区等 是。在这范围内，仍能适用地台区的分区名称的， 只有伊傸台陷 ${ }^{[1]}$ 、四川台陷及烃江台陷这三个小的 残留地台区而已。有人主张划分构造区以該处地质 发展史中的某一特定阶段(例如有人主张前震旦紀， 另有人主张古生代) 的大地构造性稹为准。笔者訩 为这是值得商榷的。因为这样便会把地质发展史中 途切断，而不能反映地稹发展员的全部。除非我們 所作的是目的在于表示某一地稹时代或某一地壳运 动期（例如呂梁期、貝加尔期、加里东期、海西期 等）的大地构造性稹的“古大地构造图”，否則这种 划分标准将会导致混乱和錯誤。因为同一地区，某 甲以它的下古生代情况为准，可以划它为地槽区; 某乙以它的上古生代性稹为根据，又有可能說它是 地台区。这便会陷入无原則的爭論, 而問題永远得 不到解决。

最后，談談关于分析和判別大地构造性稹問题 的意見。笔者訩为, 辩䚿一个地区任何发展阶段 一一目前阶段抑或以前某一阶段一一的大地构造性 稹的时候，应从全面覌点出发，抓基本特征，抓发

展主流，抓关鍵。因此，必須注意下列四点:

（1）应把該地区地质发展史中同一发展阶段的 沉积建造(地层)、构造、岩浆活动、变稹作用等各
个主要方面的資料全面地来作总的考虑，而不可片 面地、坬立地仅抓住其中某一方面的特点，作为唯 一的或絕对的标准。例如，我們不可仅抓住某一时 期的强烈的酸性岩浆活动, 㓷决定当时該处是地槽 区，而不去孝虑与这些岩浆活动同时出現的沉积建 造类型和构造类望，以至岩浆活动本身的特征。因 为不同大地构造类型的岩浆活动，有时可以有某些 相似; 大量酸性岩的发育固然为地槽区所常見，但 井非限于地槽区所特有。又如，我們不要仅仅因为 看到某些地区于地台阶段所成的地层厚度較大，就 断定䠹处当时非地台情况，还得要联系到这些地层 在岩性及其稳定性、建造类型、厚是的稳定性、形 成时的展布情况、沉积連續情况, 以及当时的构造 运动、岩浆活动、变盾作用等方面的特征，加以全 面考虑。因为地台型沉积的厚度, 在地台中以隆起 运动为主的部分固然較薄, 但以下降运动为主的部 分仍可很厚 (公䚯为标准地台的俄罗斯地台，依 茄 联大地构造图說明纬，其沉积盖层除在台 隆 ${ }^{[2]}$ 部 分較薄外，在台䧄部分厚度可 达 3,000-4,000 米 或 7,000一8,000 米，有时可㝽万米)。反过来，在 地槽区的地槽(地向斜)部分, 沉积物厚 度 固 然 很 大，但在地背斜部分也可很薄。黄汲清把沉积物的 厚度看作是区分大地构造单元的主要标准, 尀信为 地台型沉积厚度总是小的, 地槽型沉积厚度总是大 的。但据实践証明，孤立地只根据沉积物的厚筑来 制別一个地区是属于什么大地构造性质，而不去考 虑沉积建造类琹及其他特征, 那是不能解决問題的。

（2）应以該阶段的基本特征为根据，当把两个 构造区的相当发展阶段对比的时候，尤应注意此 点，而不应孤立地坑住某些由于两个构造区地质发 展史的某个阶段的具体差异所发生的、非本质的差 別, 来作为它們二者不能对比的理由。任何两个性 稹相同的基本构造单元，既有其共同的基本特征，

［1]台陷, 我文 Спнеклиза, 源自拉丁交“沒有傾觕的

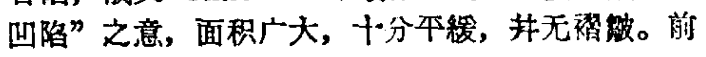
譯“台向斜”是不恰当的。

[2]台隆, 俄文 Антеклиза, 系介于台陷之問的相对隆 起部分, 面积大而地层十分平縓, 为一“消极的隆

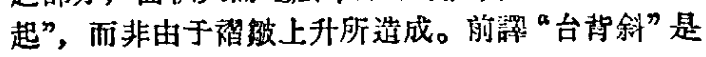
不正确的。 
也必然有其自身的特点。例如，两个构造区，当它 捫地稹发展的地台阶段，一个的运动方向以上升为 主，另一个以下降为主或升降运动交替出現。这 样，便可在地层的岩石沉积类型、岩相及其中所夹 矿床类型等方面引起某些差別: 前者地 层 厚 度 較 小，以陆相沉积为主，缺失較多，所夹矿床多为陆 相; 后者涅度較大，以海相为主，或者海陆相交替 出現，所夹仢床可为海相或海陆交替相。其次，当 时当地气候的差异，也可以发生含煤与不含煤等的 区別。文有时，由于地台阶段之后継續出現了地洼 阶段的强烈构造运动及岩浆活动，原地台阶段所形 成的地层及沉积矿床，也可发生变稹(例如地 台 型 的三水鋁土矿可以因此脫水变为一水型)。但只 要 这些地层在其建造类型、岩性及其稳定性、厚度的 稳定性，以及同时出現的构造运动、岩浆作用、变 貭作用等等各个主要方面的基本特征是属于地台型 的，則这一阶段的地台性稹仍然可以被䚯識出来， 抹与地台区进行对比。有人因为看到“"中国地台沉 积盖层的厚度較大”，以及“华北和华南的石炭二迭 紀鋁士矿一般都产于煤系中，抹常为海陆交互相， 矿物㚬为一水型”，便訩为中国东部当时不是标准 地台，而不考虑該处在地层、构造、岩浆活动等各 个主要方面所表現出来的当时的地台型基本特征， 这显然是不正确的。如果用这种思想方法去划分构 造区，那末世界上的标准地台就只有一个。如果說 俄罗斯地台为标准地台, 則北美地台就 是 不标准 的，如果說北美地台为所謂“正地台”，則俄罗斯地 台及謷变成所謂“准地台”了。因为世界上决沒有二 个地台的地稹发展史完全相同的。

（3）必須鑑別所諭的发展阶段在大地构造性盾 上的主要方面和次要方面，从而辨識当时的发展主 流究是属于活动区性稹的还是属于“稳定”区性稹
的。例如，中国东部大部分地区，当古生代(东 南 諸省为上古生代)的时候，在广大范围里，长久的 地稹时間內，其基本特征都是以属于“稳定”区性质 的占居主要地位。虽然在这个发展阶段內, 有时地 曾出現过一些局部的、短暫的、活动性較强的表 現，如較大幅度的沉降运动、地层間的不整合等。 但这些是次要的、局部的、短㟻的現象，不应㚊被 誇大姓用来掩盖及否諨代表当时发展主 流的相对 “稳定”的地台性稹。如果这些局部的、短整的次要 現象实际上抹没有超出地台型地壳运动的范畴，則 当时的地台性稹就更难抹繁了。

（4）应該抓住关䣄問題，首先加以解决。例 如，有人說，地槽型鋁士矿为海相，生于厚层石灰 岩中。他根据这一点, 便断定中国东部的石炭二迭 紀鋁士矿的沉积环境不是标准地台，抹且据此来否 䚯这一地区当时有过地台阶段的存在。其理由是, 因为这些鋁士矿层常为海陆交替相, 其頂底板尽是 海相石灰岩(其实执非如此，只是部分地区为 海相 石灰岩; 有竍多鋁土矿层实系生在陆相的粘土中， 如华北的G层鋁土矿垖是其例)。但实际上，这些鐰 土矿层是否是地台型，其关鍵問題抹非在于它們究 是海相、海陆交替相，抑或是陆相，以及顶底板是 否是石灰岩，而是在于当时的海是否是地台 型的 海，其頂底板的石灰岩是否是地台型的石灰岩。因 为地台型沉积环境汼非限于陆相，当它有海水淹浸 的时期，没有理由不可以形成海陆交替相，抹造成 海相石灰岩的頂板或底板。如果我們能从一个地区 所論的发展阶段的沇积建造、构造、岩浆活动等方 面的基本特征去全面考虑当时的大地构造性质，而 不孤立地只看到一些沉积矿休是否海陆交替相之类 的次裂特点, 則对于这一点就很易明白了。 